\title{
SUGGESTIONS FOR GLOBAL ISSUES IN LANGUAGE EDUCATION MATERIALS AND ACTIVITIES
}

\author{
Gregory Goodmacher ${ }^{1}$, Asako Kajiura ${ }^{2}$ \\ Keiwa Gakuen College, Japan \\ ggoodmacher@hotmail.com \\ Niigata University of Rehabilitation \\ dancer728@hotmail.com
}

\begin{abstract}
Universities and other centers of learning are joining with the United Nations and other international institutions to further the study of significant issues that are affecting the lives of people across the globe. Ministries of education in various countries want to have their students develop an understanding of the concept of global citizenship and the connections between the peoples of our increasingly intertwined world. In line with this, many educational institutions are including global issues education in their curricula. The English language is the predominant language of international business, globalization, medicine, international education, and politics. Billions of people are studying and using English daily. Can language teachers play a part in promoting global citizenship and creating a peaceful and sustainable world? This paper aims to answer that question and to address vital principles involved in the creation of activities and teaching materials that merge global issues content and language education. It will also provide examples of how teachers can combine content education and critical thinking skills in ways that develop grammatical knowledge and the traditional skills of reading, writing, speaking, and listening.
\end{abstract}

\section{INTRODUCTION}

Globalization affects every person on Earth twenty-four hours a day. The actions and decisions of people across the globe are altering the air we breathe, the water we drink, the food we eat, and the health care we receive. The wealthy and powerful, who own major corporations, including the media, can control the dissemination of information and shape the thinking processes of others. As a result, a small number of people, many of them English speakers, are making decisions that affect our food supply, our climate, and our freedoms. English, with a significant presence in the fields of medicine, politics, advertising, international negotiations, technology across vast areas of the world, is connected in many ways to the spread of globalization and the growth of various global problems, as well as solutions for those problems. All teachers, including language teachers, should reflect on the educator's role. Is the role of a language teacher to teach just the mechanics of a language? Should we introduce global issues into language classrooms? If yes, why is global issues content-based instruction necessary? What are good practices to follow when teaching global issues in language education (GILE) courses? This paper attempts to answer these questions and outline important educational principles for GILE educators. 


\section{DISCUSSION}

\section{Global issues?}

International institutions and researchers define global issues in various ways. The United Nations Foundation states, "The great challenges of the early $21 \mathrm{st}$ century are global in nature - issues that transcend the capabilities and resources of any one nation or sector" (2013, para1). Snarr and Snarr (2008, p. 2) contribute an additional perspective to the concept of global issues by stating that global issues can include "problems and issues that do not necessarily cross borders but affect a large number of individuals throughout the world. Ethnic rivalries and human rights violations, for example, may occur within a single country but have a far wider impact." Kip Cates offers a useful, though incomplete, list of issues that most people consider to be global. According to Cates (2015, p.24), global issues refer to "world problems such as war, hunger, poverty, oppression, racism, sexism, environmental destruction and to concepts such as peace, justice, human rights, world citizenship, social responsibility and international understanding."

The quotations above contain three essential points. First, global issues cannot be solved by one country alone. Secondly, global issues affect large numbers of people. Lastly, understanding, responsibility, and citizenship are aspects of global issues.

\section{Global Citizen Education}

Most national governments try to instill in their people a feeling of nationalism, a love for the country, and a belief that citizens are members of a priveledged group. Many local governments attempt to encourage civic pride, and many schools encourage their students to feel an attachment to tho schools. Such behaviors develop solidarity and community, which are positive points. However, excessive localism and an extreme belief in the exceptionalism of one group stimulate the development of prejudices and us-versus-them attitudes. In contrast, a global citizenship education aims to promote solidarity and create connections among peoples in all reaches of our shared planet. GILE instructors often include the concept of global citizenship in their courses. An excellent global citizen teaching resource is Empowering Global Citizens: A World Course. In the prefix, Reiners, Chopra, and Chung (2016, p. xix) explain the significance of global citizenship education:

Global citizenship education is essential for creating a world with sustainable peace - a world without poverty or hunger and where all have health and education. A world where women and men have the same opportunities, where all have clean water and sanitation, where we use renewable energies, where there are good jobs for all...A world of peace and justice for all.

Language teachers can develop lessons that teach about other peoples, about groups of nations, about the intertwined nature of our world. Lessons should make students study both differences and similarities. Language classes should increase the skills of empathy, adaptation, and self-reflection, which are interpersonal and intercultural communication skills, because these aid communication within one's community and across the globe. Intercultural communication, the United Nations, 
international volunteer organizations, voting, religion, and human rights are among many topics that intersect global citizenship.

\section{Empower Students}

Global citizenship education can also include teaching about how ordinary people work to solve local and international issues. Such lessons can lead to greater community involvement. Language teaching should empower students in manner expressed in the following definition of empowering: "Something that is empowering makes you more confident and makes you feel that you are in control of your life" (Cambridge English Dictionary, n.d.).

Empowering students and teaching languages go hand in hand. The attainment of greater communicative abilities enables students to access more sources of information, read between the lines, understand others, and become persuasive. Lessons in research, debate, rhetoric, and critical thinking help with these goals. As previously mentioned, other people around the world are making decisions about press freedom, military expenditures, pesticide safety, oil drilling in national parks, minimum wages, and many other significant matters that touch our lives. GILE teachers, while teaching language skills, should try to develop students' awareness of their power to protect themselves and their communities and their knowledge of ways to stand up for human rights.

GILE can introduce students to stories of how people their ages work to solve various problems through petitioning, writing letters to public officials, marching, joining public demonstrations and boycotts, and other forms of peaceful protest. Writing classes can include writing letters to government and corporate officials. Students can research, evaluate, and give English presentations on organizations that work to bring about positive change. As students develop better language skills and increase their knowledge of how to effect change, they may come to realize their power to do good in the world.

\section{Make GILE Content Affectively Stimulating}

One problem that many GILE teachers face is dealing with students who may lack interest in studying global issues or studying English. In numerous countries, English is a required subject that many students do not think is interesting. To increase interest in language and content matter, teachers should strive to teach with impact. As Tomlinson explains, "Materials should achieve impact. Impact is achieved when materials have a noticeable impact on learners... when the learner's curiosity, interest and attention are attracted" (1998, p.7). Nowadays, the internet is a great source of powerfully affective videos and images that instructors use for teaching purposes.

Photojournalism websites offer some of the most intellectually and emotionally stimulating visual aids. Goodmacher (2005) explains that "the field of photojournalism excels in creating websites that often touch, sometimes upset, and always stimulate the minds and hearts of viewers and readers (for specific suggestions on how to use photojournalism sites in language education, read the article). 


\section{Think Globally Act Locally or Teach Globally and Locally}

Helping students to connect global issues with local issues and vice versa is an integral aspect of GILE. When teaching many global issues, educators should keep in mind the slogan "Think globally, act locally." When teachers create educational experiences in which students investigate and try to solve global problems in a local context, student interest is often greater than when teachers within the walls of a classroom explain global issues as problems that only occur elsewhere.

One useful exercise is to require students to walk around their hometowns with a grandparent or someone of approximately the same age as a grandparent. Each student interviews his or her partner about air, water, and other environmental changes that have taken place since the elder was the same age as the student. Students also ask about how daily work, social interactions, food, and so on have changed. The interview can take place in the first language, but students must use English to produce written or oral reports. This activity usually results in students learning about local environmental changes that mirror the global issues they are studying. The last time I did this activity, almost all the students reported air and water quality deterioration. The students who reported improvement were from regions that used to be involved in coal mining or other heavy industrial processes that no longer continue.

\section{Experiential Learning and Field Trips}

Immersing oneself in an endangered habitat stimulates all of the physical senses. Whereas, studying about an endangered habitat in a classroom does not. Active, experiential learning often leads to deeper learning. As Beard and Wilson (2006, p.2) state, "Active engagement is one of the basic tenets of experiential learning: experiential learning undoubtedly involves the "whole person, ' through thoughts, feelings and physical activity."

Every year I take my students on a field trip to a lagoon for an experience that connects global issues with local issues, promotes the learning of local knowledge, and teaches how a local NPO works to protect native species. In small ponds, members of the NPO grow an endangered species of wild rice, called makomo in Japanese, which is a food for endangered geese and other fowl that winter in Japan. The students ride on traditional wooden boat into the center of the lagoon. They stand in thigh-high water to plant the makomo. Walking in the muddy lagoon is hard work. Students also fill many bags with garbage. The NPO members also teach them about invasive species, about making necklaces with native plants, and about using native plants for food. The field trip culminates with a meal made with native plants. These modern students receive insights into environmental issues and their cultural history and physical stimuli they cannot get in a classroom.

A part of a successful fieldtrip involves pre- and post-experience language activities. Planning in English how to get to the lagoon by public transportation, listening to my English explanation about the field trip, translating conversations between the NPO members and me, and writing reflection essays were communication activities tied to the aforementioned trip to a lagoon. 


\section{Personalization}

Personalization of global issues content is crucial. Associated with the concept of "teach globally and locally," personalization of content allows students to express their opinions, preferences, desires, worries, and hopes regarding the studied content. Personalization of lessons enhances learning. As the British Council explains, personalization "involves true communication, as learners communicate real information about themselves...It makes language relevant to learners, makes communication activities meaningful, and also helps memorization" (2006, para.1).

Unfortunately, a majority of textbooks and authentic materials that GILE practitioners use or adapt lack questions that link content with the lives of students. A simple action to promote personalization is the creation of questions that students must reflect on their personal experiences or desires to answer. Example questions for four GILE topics are below.

Table 1: Examples of Questions that Connect Students with Global Issues

\begin{tabular}{|l|l|}
\hline GILE Topic & Questions Students Ask Each Other \\
\hline Violent Media & Do you enjoy violent movies or video games? Why or why not? \\
\hline Garbage & Have you ever littered? If yes, why? In no, why not? \\
\hline Prejudice & $\begin{array}{l}\text { Have you ever experienced discrimination? If yes, explain. If no, why } \\
\text { not? }\end{array}$ \\
\hline Consumerism & What do you want to buy next? Do you need it? \\
\hline
\end{tabular}

\section{Foreigners as Teaching Materials}

The foreigners on our campuses and in our communities are useful human resources for teaching about other perspectives. Ask international students to give presentations. When teaching specific issues, ask the international students how people in their countries handle those same issues. Assign your native students and the international students to interview each other.

Send letters or call foreign embassies and consulates to ask for their cooperation. One of the duties of their staff is educating others about their homelands. You can often receive useful books, maps, posters, and other documents in English, not to mention speakers. The ambassador of Angola visited my small college in a remote area of Japan after I wrote to express my interest in our learning about Africa. His talk had a lasting impact on my students.

\section{Review}

Opportunities for meaningful review are necessary for all people learning a language. However, GILE students have an additional learning challenge. GILE courses expose students to content-specific jargon, knowledge, and skills that they must know or develop in addition to general language aspects that non-GILE courses cover. Teachers must design lesson plans and syllabi that recycle information in different formats. For example, a short video can reinforce a reading. Students can be assigned to translate information in graphs into texts. 


\section{Critical Thinking about Media}

GILE requires critical thinking education for numerous reasons. In the age of the internet, advertising and news, both trustworthy and untrustworthy, are engulfing humanity on a daily basis. Students who are not taught to actively consider the sources of their news will passively believe incorrect information. Media bias is a worthy topic to include in many GILE courses. Students can be assigned to discover the ownership of major newspapers, websites, and publishers and report back to the class. Ask your students if a media company that is owed by a corporation that makes weapons, nuclear power, and has a record of polluting the earth will honestly and objectively cover those topics. Another suggestion is to compare and contrast articles about the same news event from different news sources, such as Al Jazeera and Fox News. Also, students should be asked to reflect on why they hold certain ideas about people from other countries. Students will realize that movies, television programs, and news reports communicate stereotypes. Students should learn how media shapes the thinking of the average person.

\section{Lower and Higher Order Thinking Skills}

When deciding learning objectives, learning taxonomies are handy tools for GILE practitioners. One learning taxonomy that has influenced educators worldwide is the Taxonomy of Educational Objectives (Bloom, Engelhart, Furst, Hill, \& Krathwohl, 1956). Almost fifty years later two researchers associated with Bloom revised that taxonomy. The revised version, authored by Anderson and Krathwohl (2001), is A Taxonomy for Teaching, Learning, and Assessment. One of many major contributions to education that the authors of these books have made is the description of cognitive processes and what Anderson and Krathwohl describe as the creation of a hierarchical framework that represents the cognitive processes from lower order thinking (LOT) to higher order thinking (HOT).

Bloom`s original framework arranged the cognitive process in the following order: knowledge, comprehension, application, analysis, synthesis, evaluation. The revision, which changed the terminology and repositioned the last two levels, is this: remember, understand, apply, analyze, evaluate, and create.

Lesson units that require all of the cognitive processes listed above will provide students with exercises that "ideally lead students from memorizing basic structures to understanding more complicated structures, and to gaining proficiency with higher-level thinking processes" (Goodmacher, 2016, p.55). If students who are studying English and climate change did the exercises in the table below, all of the above thinking processes would be engaged. The students would also think about a global issue from both an international and local perspective. The students could also work individually and in small or large groups. 
Table 2: Educational Activities Tied to Cognitive Processes

\begin{tabular}{|l|l|l|}
\hline HOT & Cognitive Process & Suggested Educational Activity for Both Content and Language \\
\hline HOT & Synthesis & $\begin{array}{l}\text { Evaluate student-made videos and choose the most persuasive video. } \\
\text { ecofriendly campus. }\end{array}$ \\
\hline HOT & Analysis & $\begin{array}{l}\text { Decide if various statements support the positons of climate change } \\
\text { deniers and believers. }\end{array}$ \\
\hline LOT & Applying & $\begin{array}{l}\text { Based on studied information, choose the most appropriate renewable } \\
\text { energy sources for your hometowns. }\end{array}$ \\
\hline LOT & Comprehension & $\begin{array}{l}\text { Examine graphs that explain how human activities change the climate } \\
\text { and express the graphic meaning either verbally or in writing. }\end{array}$ \\
\hline LOT & Knowledge & $\begin{array}{l}\text { Memorize vocabulary for speaking about global warming gases and } \\
\text { activities that release those gases. }\end{array}$ \\
\hline
\end{tabular}

\section{CONCLUSION}

The pedagogically useful principles explained in the paper were developed and refined over a period of approximately thirty years of teaching and researching ELT. They are not definitive guidelines for every GILE course. The suggested activities are ones that were successful in the authors' classrooms. Each teaching environment has its own unique culture: The expectations, skills, motivation, and background knowledge of students, teachers, and administrators differ. Teachers will find that some of the advice given in this paper is appropriate for their students while other advice might be inappropriate. Nonetheless, try out the suggestions at least once. Observe your students, and reflect on how they interact. After that, decide to reject completely or to adapt the ideas. Preparing for a GILE course often takes more preparation time than preparing for a general English course, but GILE is rewarding. Empowering students with language skills and content knowledge can be a significant experience for both you and your students. Many global problems (habitat destruction, income inequality, prejudice, the spread of nuclear weapons, etc.) seem to be worsening, GILE, which develops and promotes language skills, global and local education, and critical thinking, is a type of teaching that leads students to seek for solutions to world problems.

\section{REFERENCES}

Anderson, L. W. \& Krathwohl, D. R. (2001). A taxonomy for learning, teaching, and assessing: A revision of Bloom's taxonomy of educational objectives. New York: Addison Wesley Longman.

Beard, C. \& Wilson, J. (2006). Experiential Learning, a best practice handbook for educators and trainers. London: Kogan Page.

Bloom, B. S., Engelhart, M. D., Furst, E. J, Hill, W. H., \& Krathwohl, D. R. (1956). Taxonomy of educational objectives, handbook I: Cognitive domain. New York: David McKay Co Inc.

British Council. (2006). Personalisation. Retrieved from https://www.teachingenglish.org.uk/article/personalisation

Cates, K. (2015, October). What are global issues? Global Issues in Language Education Newsletter, 78, 24.

Empowering. (n.d.) In Cambridge English Dictionary. Retrieved from http://dictionary.cambridge.org/dictionary/english/empower 
Goodmacher. G. (2005). Education with impact-developing lessons for language and global issues education with photojournalism sites. Folio Journal of the Materials Development Association MATSUDA 9. (2), 1820.

Goodmacher, G. (2016). Learning taxonomies, critical thinking, and global issues content-based EFL. Critical Thinking and Language Learning III. (1), 50-61.

Reimers, F., Chopra, V., \& Chung C. (2016). Empowering global citizens: A world course. North Charleston: Createspace Independent Publishing Platform.

Snarr, M.T., \& Snarr N. D. (2008). Introducing global issues. Boulder, CO: Lynne Rienner Publishers.

Tomlinson, B. (1998). Introduction to materials development in language teaching. Cambridge, UP: Cambridge.

United Nations Foundation. (2013). Global issues. Retrieved from http://www.unfoundation.org/what-we-do/issues/ 